\title{
DYNAMIC GEOMETRY ENVIRONMENTS AS COGNITIVE TOOL IN MATHEMATIC EDUCATION
}

\author{
Vladimír POLÁŠEK, Univerzita Tomáše Bati ve Zlíně \\ Lubomír SEDLAČEK *, Univerzita Tomáše Bati ve Zlíně
}

Přijato: 9. 10. 2015 / Akceptováno: 23. 11. 2015

Typ článku: Teoretická studie

DOI: $10.5507 /$ jtie.2015.017

Abstract: In this paper we deal with a possibility of the application of dynamic and interactive geometry software in the mathematics teaching at our schools. We offer their brief characteristics and describe their integration among cognitive computing technologies. The greater attention is paid to GeoGebra Software in order to show its specific use as a cognitive tool. We describe the importance and the role of dynamic geometry programs in the discovery of new knowledge by the experimentation and manipulation of the interactive construction. Each phase of this process we generally define and then illustrate with a specific example.

Key words: cognitive technology, dynamic and interactive geometry, GeoGebra, experiment, hypothesis, verification, proof.

\section{PROSTŘEDÍ DYNAMICKÉ GEOMETRIE JAKO KOGNITIVNÍ NÁSTROJ V MATEMATICKÉM VZDĚLÁVÁNÍ}

Resumé: V př́spěvku se zabýváme jednou z možností využití programů dynamické a interaktivní geometrie ve výuce matematiky na našich školách. Nabizime zde jejich stručnou charakteristiku a popisujeme jejich začleněni mezi počitačové kognitivní technologie. Vètši pozornost věnujeme programu GeoGebra s cílem ukázat jeho konkrétní využití jako poznávacího nástroje. Popisujeme význam a roli programi dynamické geometrie při objevování nových poznatki̊ experimentováním a manipulací s interaktivni konstrukcí. Jednotlivé fáze tohoto procesu obecně definujeme a následně ilustrujeme na konkrétním přikladu.

Klíčová slova: kognitivní technologie, dynamická a interaktivní geometrie, GeoGebra, experiment, hypotéza, verifikace, důkaz.

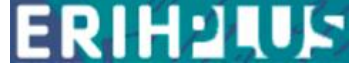

*Autor pro korespondenci: 1sedlacek@fai.utb.cz 


\section{Introduction}

The area of computer technologies, which in recent years has gone through a huge development, has become an everyday part of the school tuition and has an impact on the mathematics teaching at our schools. Almost at every school mathematics teachers have already had at their disposal some applications in computer algebra systems or a dynamic and interactive geometry. The suitable presentation of the curriculum using these applications then improves and facilitates the educational work and may lead to a significant increase in the clarity and effectiveness of the mathematics teaching. An illustrative conception, which is usually the first stage of mathematical knowledge, is very important. The teaching, in which the final relationships and structure are presented to students without mention of their origin, and does not put enough accent on the illustrative content of the individual mathematical concepts, leads to the formalism in the education. There is often also a paradoxical situation that a student, who solves the task by mechanically learned algorithms and methods, solves it without understanding. This formally acquired mathematics is almost inapplicable in practice and confirms the opinion of major part of the population that most of mathematical knowledge, taught at the school, is useless. Therefore, it is necessary to present the curriculum to realize the development of the cognitive abilities of students, their creative thinking, imagination and the discovery and evaluation of contexts (Hejný, Kuřina, 2001). Just computer technology may serve very well to do this, especially cognitive technologies.

\section{Cognitive Computer Technologies in Mathematics}

In the context of a new approach to the use of technologies in the tuition, the computer technologies acquire the role of cognitive tools. According to Pea (1987) these technologies should help students to think constructively, to enable to take them beyond their frontiers of the knowledge and to involve them in cognitive activities, which would otherwise be unable to do it. The computer technologies as cognitive tools are therefore a major shift from the traditional concept of the technology, which served students only as an access to information. Currently it is regarded as a tool for development of original and independent thinking. Among cognitive technologies used in mathematics teaching we can count (Heide, 1997):

- Computer algebra systems (CAS) - Mathematica, Maple, Derive, Matlab ...

- Micro universes - Logo, Imagine ...

- Dynamic geometry environment - Geogebra, Cabri Geometry Sketchpad, Cinderella, Euclid, Geonext ...

- Computer lab - ISES, LegoDacta ...

- Graphing Calculator - TI-80, Casio etc.

\section{Interactive and Dynamic Geometry}

In the professional literature the term interactive and dynamic geometry often refers to the applications by which the user can make geometric construction on the monitor screen and which can be subsequently interactively changed. According to Vaníček (2001), therefore a geometry in such programs is interactive. Applications, in which constructed objects are not static but we can manipulate with them after the creation, change their shape, size and position in the drawing plane, while maintaining a predefined relationship between objects, we call dynamic geometry programs. That area geometry, in which the 
movement of an object has substantial influence on the insight into the situation and on the problems solving, then we call dynamic geometry.

An essential element that makes the geometry really dynamic is the ability to change the loose elements of already finished construction, while the rest of the structure will be redrawn automatically so as to preserve all the links that have been in the construction given (perpendicular lines will still be normal, parallel lines parallel etc.). E.g. if it is constructed general triangle and its three altitudes as the perpendicular lines drawn upon the side of the triangle from the opposite top which intersect at a single point (orthocentre), then if we move, using the mouse, any vertex of the triangle, both sides of a triangle and its altitudes will be redrawn. The altitudes will again be perpendicular lines to the corresponding side passing through the opposite vertex and again intersect at a single point. Thus, when handling, a triangle passes particular positions that are immediately redrawn and originally static construction is continuously changing. The user can then visually find out that the altitudes indeed "always" (for each triangle) intersect at a single point, and that there was therefore no mere coincidence given by the chosen shape of a triangle. This technically enables a new way of testing hypotheses or exploring new features.

Among the most frequently used programs in mathematics teaching in the field of dynamic geometry environment we can include: GeoGebra, Cabri Geometry II Plus, Cabri 3D, Sketchpad, Cinderella and many others.

\section{Geogebra}

GeoGebra is the most widely used software in school practice. It combines functions of dynamic geometry systems with spreadsheets and CAS systems and enables the creation of dynamic web pages. It is free for educational and non-commercial purposes. The user interface is very nice and although it looks very simple, it has very powerful tools (Gergelitsová, 2011).

It is an application that can be run without an internet connection, when installed on a personal computer, but it can also run within a web browser. The only condition is to install the JRE (Java Runtime Environment).

GeoGebra basic functionality is very similar to other geometric applications in the field of dynamic geometry. You can insert objects (such as point, line, line segment and circle), perform basic operations (construction of perpendicular lines, parallel lines, axis angle...), to apply some projections (axial and central symmetry, homothety, circle inversion ...) and to step through the construction.

But additional it contains functions that similar programs don't offer. There is possible equivalent object control as by a geometric projection plane, and by an algebraic window or eventually by a table view. It also allows the creation and storage of macro constructions (custom tools, custom user functions), the export of the projection plane contents to vector and raster formats, and supports communication of the applet with the script within a web page. The resulting documents can be saved in a format of GeoGebra files, pictures or objects of websites. It is also possible to put them on a free server tube.geogebra.org, where can be also attached descriptions and comments, and in this way to share learning materials.

As the advantage we can also mention the large community of users, which creates a database of learning materials on the server www.geogebra.org. In addition to the basic application version there is also an HTML version 52, which also works on tablets, but it 
is also prepared native application for tablets with the operating system Apple iOS and Google Android (Heczko, 2013).

\section{Methodology of the Cognitive Process}

The discovering of new knowledge by manipulation with the interactive construction is a key feature of all dynamic geometric systems. Pupils can, by using these systems, change the assignment of tasks while directly watch the behaving of all the construction as a result of these changes. Because the constructed object undergoes while changing assignment of task by many configuration positions, the pupils can easier and faster discover general solutions in an environment of the dynamic geometry.

Besides, the experimenting, by the changing of the input parameters, is also for the pupil important to be able to immediately reject wrong approach that by chance work for any of the configuration task, but it generally doesn't work. There is an immediate feedback and the time, at which the student finds that the way to the solution, which was originally chosen, is not correct, shortens. In addition, the knowledge discovered by the pupil himself encourages his inner motivation and creative thinking. This heuristic teaching method, however, must be carefully thought out and the whole learning process has to be managed and checked by a teacher who divides it by the proper instruction into different stages (see Fig. 1), in which he lets the student work independently.

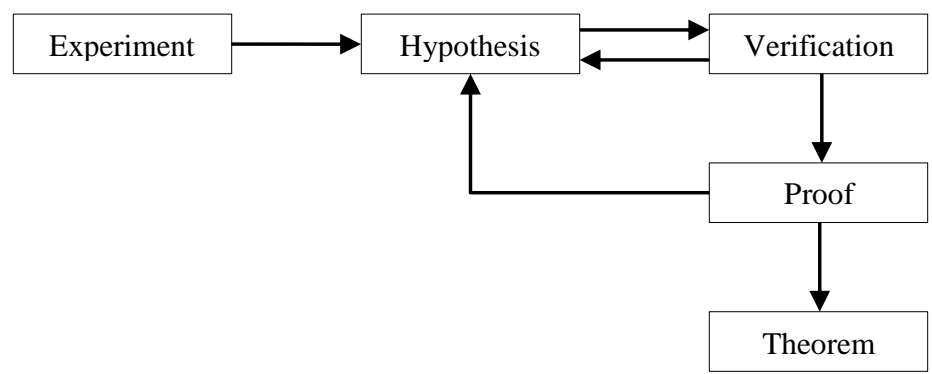

Fig 1: Diagram of the individual stages of the cognitive process

In the first stage of the experiment, we explore the attributes of geometric formations entering the structure. We find their mutual contexts and logical relationships by using appropriate means from a set of research tools in the dynamic geometry.

On the basis of this investigation we will formulate a hypothesis. It means a presumption which can become a theorem.

We undergo this statement to verification. We again examine the validity of the hypothesis by various modifications of construction, whereby it can be evaluated numerically or visually by special processes, precise geometric constructions and measurements. During the verification, we can achieve a verification of formulated hypothesis validity as well as its refutation of finding a counterexample. Alternatively, we can modify the hypothesis after the verification.

In the penultimate stage, we perform a mathematical proof and we say a theorem based on its validity. At this stage it is necessary to emphasize the need of mathematical 
proof, to arouse students' curiosity, the effort to justify and prove that the given result can be accepted. The verification of the formulated hypothesis is for students, thanks to the precision of construction, which is for example 10 decimal places at the Cabri Geometry II Plus, so "convincing" that they often lose need of further mathematical proof (Gillis, 2005). The verification cannot be considered a proof. We mustn't allow pupils to interchange these two procedures.

It is therefore necessary to distinguish the verification process from the process of a mathematical proof. The students perform both independently, but the verification is carried out completely in the dynamic geometry environment while the mathematical proof is done without the use of a computer software.

\section{Illustration of the Experiment}

In this section we give a particular example of the experiment with individual stages of cognitive process. Pupils handle with interactive construction, monitor changes in this construction, to discover the solution to the given problem.

\section{Problem}

It is given: a straight line $p$ and the points $A, B, C$ such that a straight line $A B$ is parallel to the line $p$ and point $C$ lies on the line $p$. Determine a set of positions orthocenter of a triangle $A B C$ if its vertex $C$ moves along a straight line $p$.

\section{Commentary on the Problem}

Assigned task difficulty corresponds to the knowledge and skills of the third year high school students. We recommend solving this task in mathematical lessons. The problem is solved using GeoGebra software.

\section{Experiment}

Let us construct a triangle $A B C$ and the line $p$ according to the assignment and the straight lines on which the altitudes of the triangle $A B C$ are located. Let us mark their intersection by letter $O$. Using Move Tool, we drag the mouse pointer to point $C$ and move it on a straight line $\mathrm{p}$ and study the changing position of the point $O$. By activating the Trace Tool in the Context Menu we can gradually draw a trajectory of the point $O$ by its movement. We can also use Locus Tool to show the trajectory of the point $O$ immediately. The set of all points $O$ given by the point $C$ moving on the straight line $p$ seems to be a parabola (see Fig. 2). 


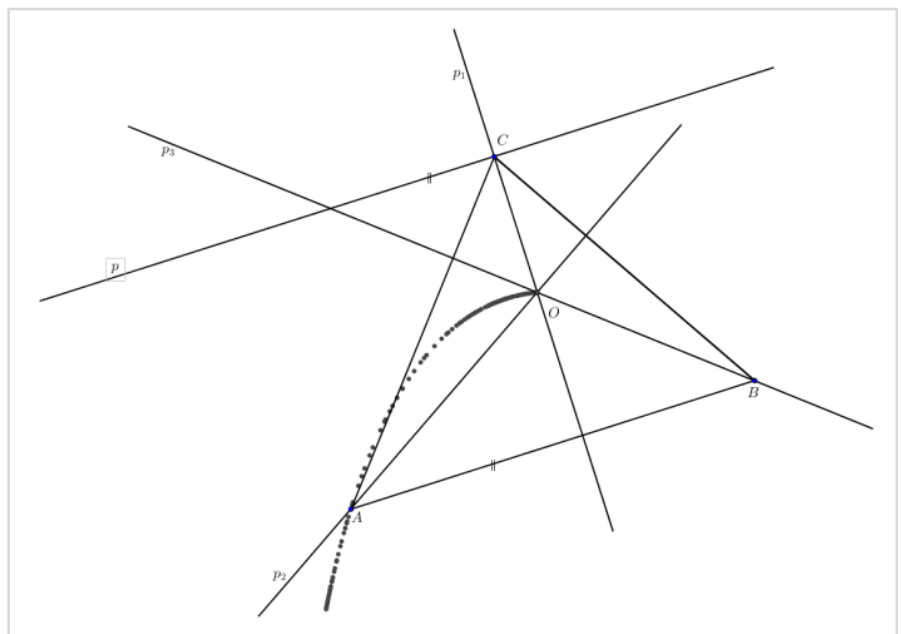

Fig 2: The process of plotting the curve by activating Trace Tool at the point $O$

\section{Hypothesis}

The set of all orthocenters $O$ of given triangles $A B C$ is a parabola passing through the vertices $A, B$.

\section{Verification}

In the case of the invariance of the whole construction, we predicted that the searched set of points can be a parabola. Whether this hypothesis stands up well in a case of the change of the construction input parameters, we will verify at this stage. We handle loose (vertices $A, B$ ) and also partly bounded objects and points of the construction (line $p$, point $C$ ) and monitor whether the searched set of points is still the parabola even under these conditions. In studying the construction at this stage of experimentation we try to make configuration layouts of determining figures as general as possible. Therefore we are looking for all possible limit and special situations. 


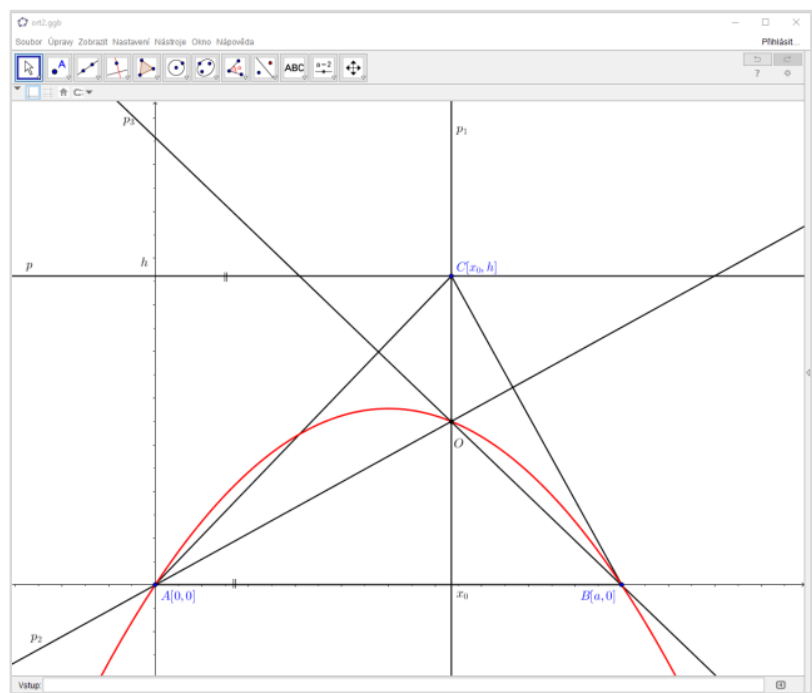

Fig 3: Position of the construction suitable for the Proof

\section{Proof}

Let us choose arbitrarily but firmly $a>0, x_{0} \in R, h \in R$. Let us place a triangle $A B C$ and line $p$ into a coordinate system so that $A[0,0], B[a, 0], p: y=h, C\left[x_{0}, h\right]$ (see Fig. 3). We will determine the searched point $O$ as an intersection of two lines $p_{1}, p_{2}$, on which lie altitudes perpendicular to the sides $A B$ and $B C$. A line which is perpendicular to the side $A B$ has a general form $p_{1}: x-x_{0}=0$. To determine the general form of the equation of a straight line $p_{2}$, which is perpendicular to the side $B C$, we determine first the normal vector $C-B=\left(x_{0}-a, h\right)$. Then the general form of the equation for the line $p_{2}$ is $p_{2}:\left(x_{0}-\right.$ a) $x+h y+c=0$, where $c=0$, because the line passes through the origin, so $p_{2}:\left(x_{0}-\right.$ a) $x+h y=0$. The coordinates of the point $O$ can be found as a solution of the equation system

$$
\begin{aligned}
x-x_{0} & =0 \\
\left(x_{0}-a\right) x+h y & =0 .
\end{aligned}
$$

It means $x=x_{0}$ and $y=-\frac{1}{h}\left(x_{0}-a\right) x_{0}$. This relation can be rewritten into the form

$$
y=-\frac{1}{h}\left(x_{0}-\frac{a}{2}\right)^{2}+\frac{a^{2}}{4 h},
$$

which is the equation of a parabola with a vertex at the point $\left[\frac{a}{2}, \frac{a^{2}}{4 h}\right]$.

Based on the above proof, we can accept the hypothesis and consider it to be a theorem.

\section{Other Modification of the Problem}

The assignment of the example can be modified so that the straight line $\mathrm{p}$ will be assigned arbitrarily (see Fig. 4). 


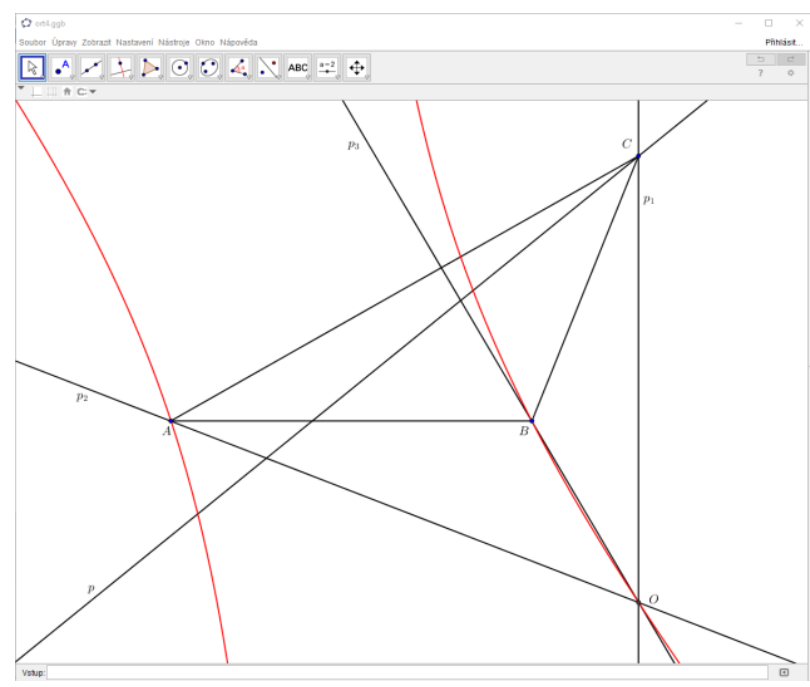

Fig 4: A line $p$ is assigned arbitrarily

By manipulating the interactive construction the students can easily find that the problem has multiple solutions. At a certain construction configuration layout, a set of all orthocentre in a given triangle can also be a hyperbole or straight line.

\section{Discussion}

As shown by some studies in recent years (see Laborde (2006), Vaníček (2009), Cabri (2009) for more information), dynamic and interactive geometry software, when appropriately incorporated and used, can positively influence the school geometry teaching. Based on this research we can summarize the impact of the integration of dynamic geometry on learning and pupils' results in two major benefits (Robová, 2012):

- A positive impact on the performance of pupils and on the learning process especially from the point of view of understanding of geometrical concepts,

- a support of the experimental work of pupils, discovering hypotheses and facilitation their verification.

Robová (2013) further notes that the recent researches focused on the influence of a dynamic geometry software on the formation of hypotheses (Gillis, 2005) show that some students do not distinguish between a hypothesis (inductive method) and a proof (deductive method) when working with environments of dynamic geometry. Pupils do not feel the need to prove the discovered hypothesis, due to software they are convinced of their validity.

The question is whether the "authority" of the computer does not lead some pupils to disinclination to the proving, or, on the contrary, whether properly presented problems encourage pupils' needs of substantiation, as well as some studies demonstrate (Laborde (2006), Abdelfatah (2011)). However, currently we do not have definite conclusions, 
which would show dynamic geometry software impact on pupils' skills in proving hypotheses. The latest research carried out in this area has not been yet possible to generalize.

\section{Conclusion}

Dynamic geometry systems provide a virtual environment that allows students to experiment, explore mathematical knowledge, generate hypotheses, visualize their ideas and thus build a constructive way to the cognitive process (Vaníček, 2009). Against the traditional concept of the teaching that is often limited to a mere transmission of information (transmissive teaching) or it only gives instructions on how to proceed (instructive teaching), using these technologies in the tuition can develop deeper cognitive abilities of students.

The fact that the teacher deliberately evokes mathematical problems by using these applications so that he makes pupils to arouse strong motivation interest is a basic assumption for successful educational work. Students are placed in a situation in which they become "discoverers" of new knowledge. Based on this, they can then generate hypotheses, which they further validate and thereby gradually reveal the characteristics of relevant mathematical models. They discover by themselves new relationships and regularities, which encourages their inner motivation and creative thinking. The tuition becomes constructive and even arouses the emotional experience from the new discovered fact.

There remains a question to be answered whether the appropriate choice of the problem in an environment of dynamic geometry arouses pupils' necessity of a deductive proof formulation.

"People can generally remember 10\% of what they read, 20\% of what they hear, 30\% of what they see, 50\% of what they see and hear, 70\% of what they say and write, $90 \%$ of what they say and do." (Dale, 1969).

\section{Literature}

Abdelfatah, H. A. (2011). Story-based Dynamic Geometry Approach to Improve Attitudes toward Geometry and Geometric Proof. The International Journal on Mathematics Education, Vol. 43, No. 3, 441-450. ISSN 1863-9704.

Cabri efficiency. CABRILOG Innovative Maths Tools. [online]. (C) 2009 [cit. 2015-11-12]. Retrieved from http://www.cabri.com/educative-software.html Dale, E. (1969). Audiovisual methods in teaching. New York: Dryden Press.

Gillis, J. M. (2005). An Investigation of Student Conjectures in Static and Dynamic Geometry Environments. Auburn : Auburn University. Dissertation. 171 p. Retrieved from http://etd.auburn.edu/handle/10415/854.

Heczko, M. (2013). Využití geometrických aplikací ve školské matematice. [online], 2001. Retrieved from http://trilian.ujep.cz/svoc/2013/k6/Heczko.pdf.

Gergelitsová, Š. (2011). Počítač ve výuce nejen geometrie průvodce GeoGebrou. Praha: Generation Europe. ISBN 978-80-904974-3-6.

Heid, M. K. (1997). The technological revolution and the reform of school mathematics. American Journal of Education, Vol. 106, No. 1, 5 -61. 
Hejný, M. \& Kuřina, F. (2001). Dítě, škola a matematika. Praha: Portál. ISBN 80-7178581-4.

Hejný, M. \& kol. (1989). Teória vyučování matematiky 2. Bratislava: SPN. ISBN 80-0800014-7.

Laborde, C., Kynigos, C., Hollebrands, K. and Strässer, R. (2006). Teaching and Learning Geometry with Technology. Handbook of Research on the Psychology of Mathematics Education: Past, Present and Future, A.

Gutiérrez, P. Boero (eds.), p. 275-304, Sense Publishers.

Pea, R. (1987). Cognitive technologies in mathematics education. In A.H. Schoenfeld (Ed.), Cognitive science and mathematics education Hillsdale, $\mathrm{NJ}$ :

Erlbaum, 89-122.

Robová, J. (2012). Výzkumy vlivu některých typů technologií na vědomosti a dovednosti žáků v matematice. Scientia in educatione 3(2), 79-106. ISSN 1804-7106.

Robová, J. (2013). Role programů dynamické geometrie při objevování a dokazování hypotéz. In Sborník př́spěvků 6. konference Užití počítačů ve výuce matematiky. Katedra matematiky, Pedagogická fakulta Jihočeská univerzita v Českých Budějovicích, 296 - 304. ISBN 978-80-7394-448-3

Thagard, P. (2001). Úvod do kognitivní vědy. Praha: Portál, 2001. ISBN 807178 $-445-1$.

Vaníček, J. (2001). Dynamická geometrie. [online], 2001. Retrieved from http://www.pf.jcu.cz/cabri/temata/dynamgeo/dyngeo.htm.

Vaníček, J. (2009). Počítačové kognitivní technologie ve výuce geometrie. Praha: UK Pedagogická fakulta. ISBN 978-80-7290-394-8.

Vaníček, J. (2000). Kognitivní technologie. [online], 2000. Retrieved from http://eamos.pf.jcu.cz/amos/kat_mat/externi/kat_mat_9782/k11.htm. 